\title{
GROWTH DIFFERENCES IN DIFFERENT BIOTYPES OF THE HYBRID COMPLEX OF COBITIS ELONGATOIDES × COBITIS TANAITICA (ACTINOPTERYGII: CYPRINIFORMES: COBITIDAE) IN THE OKNA RIVER (DANUBE RIVER BASIN), SLOVAKIA
}

\author{
Jakub FEDORČÁK ${ }^{1 *}$, Ján KOŠČO ${ }^{1}$, Karel HALAČKA², and Peter MANKO ${ }^{1}$ \\ ${ }^{1}$ University of Prešov, Department of Ecology, Prešov, Slovakia \\ ${ }^{2}$ Institute of Vertebrate Biology, Czech Academy of Sciences, Brno, Czech Republic
}

Fedorčák J., Koščo J., Halačka K., Manko P. 2017. Growth differences in different biotypes of the hybrid complex of Cobitis elongatoides $\times$ Cobitis tanaitica (Actinopterygii: Cypriniformes: Cobitidae) in the Okna River (Danube River basin), Slovakia. Acta Ichthyol. Piscat. 47 (2): 125-132.

\begin{abstract}
Background. Many of Cobitis subpopulations exist as diploid-polyploid hybrid complexes where polyploid gynogenetic females act as "sperm parasites" of diploid individuals. In addition to sexual strategy, the life history of such individuals is also affected by their growth performance. In order to elucidate unknown aspects of the Cobitis hybrid complexes we decided to identify differences in the annual size increments between individuals representing different ploidy and sex, and to compare the condition factor expressed by length-weight $(L-W)$ relation within the same ploidy and sex groups.

Material and methods. In total, 158 specimens representing Cobitis elongatoides (Băcescu et Mayer, 1969) × Cobitis tanaitica (Băcescu et Mayer, 1969) hybrid complex were caught in August and September 2014, of which 132 were analysed. The fish were caught in the Okna River (Danube River basin), Slovakia. Sex was determined based on externally visible morphological features or based on microscopic observation of the gonads. Ploidy level was determined by means of flow cytometry on fin clips taken from each specimen. Age was estimated based on the total number of annuli visible on vertebrae. All statistical models were performed in the R statistical environment.

Results. Sex ratio varied within age classes, with $3+$ fish primarily composed of females and, $4+$ fish mostly triploid. Maximum back-calculated lengths for diploid females were obtained up to $3+$, and for the $4+$ age group for triploid. $L-W$ relations for adult males and females also differed significantly, but did not vary between diploid and triploid females. There were differences in at specific body lengths for Cobitis with different ploidy level. Diploid males were characterised by short annual age and length increments during the first two years of life. Annual increments in diploid females were highest overall though their frequency decreased after the reaching the fourth year of life (3+). On the contrary, annual increments in triploid females were the lowest within all groups until their fourth year, thought their frequency in the oldest age group (4+).

Conclusion. In our study, we first confirmed that yearly increments and maximal age of Cobitis individuals are affected by different ploidy. Contrary, the $L-W$ relations of gutted diploid and triploid females did not differ and they were affected only by sex. We suggest that the intensity of growth is more affected by ploidy, while the $L-W$ of Cobitis is determined by intensity of feeding and stage of gonad development at the local conditions during season. Therefore, in the future studies of Cobitis growth and condition parameters the ploidy level of individuals should also be considered.
\end{abstract}

Keywords: annulus, back-calculated length, loach, clone, polyploidy

\section{INTRODUCTION}

The genus Cobitis Linnaeus, 1758 is represented by approximately 70 small, bottom-dwelling fish species widely distributed throughout Europe and Asia (Kottelat 2012). The majority of the Cobitis populations in central and eastern Europe are in fact mixed diploid-polyploid assemblages, with diploid and/or polyploid hybrids coexisting with at least one of the parental species, the males of which participate in the reproduction of the asexual (hybrid) forms (Vasil'ev et al. 1989, Boroń 1999, 2003, Janko et al. 2007, 2012).

In Slovakia, members of the genus Cobitis are mostly found in slow flowing lotic ecosystems (Koščo et al. 2008). Slovak Cobitis are represented by pure diploid Danubian spined loach, Cobitis elongatoides Băcescu et Mayer, 1969, and by the mixed diploid-polyploid hybrid complex of Cobitis elongatoides $\times$ Cobitis tanaitica Băcescu et Mayer, 1969 (see Lusk et al. 2003, Lusková et al. 2004, Papoušek 
et al. 2008) (C. tanaitica is known as the Don River spined loach). This hybrid complex has diploid, triploid, and rarely tetraploid male and female forms, with triploid females predominating in the majority of populations.

All Cobitidae are currently classified as endangered (Anonymous 2015) in Slovakia and have been protected under Slovak law since 2003 (Anonymous 2003), mainly due to habit deterioration (Pekárik et al. 2008).

The occurrence of diploid-polyploid Cobitis populations in central Europe casts doubt on the results of previous growth studies that do not provide genetic identification of the specimens examined (Krčál 1965, Erős 2000). Meanwhile, sexual dimorphism due to the different life-history traits of males and females of C. elongatoides was only partially examined by Kotusz (2000, 2008). Further examination of age and growth of C. elongatoides could help in our understanding of sexand ploidy-dependent differences. Consequently, the main objective of this study was to identify differences in the annual size increments and $L-W$ relation values of individual of differing ploidy and sex.

\section{MATERIAL AND METHODS}

Study area and sampling. This study was conducted on the Okna River $\left(48^{\circ} 43^{\prime} \mathrm{N}, 22^{\circ} 07^{\prime} \mathrm{E}\right.$; Danube River basin) in eastern Slovakia. The river is characterised by a slow flow and the bottom substrate was generally sandy with mud and clay.

The local fish assemblage consisted of the topmouth gudgeon, Pseudorasbora parva (Temminck et Schlegel, 1846); white-finned gudgeon, Romanogobio vladykovi (Fang, 1943); roach, Rutilus rutilus (Linnaeus, 1758); chub, Squalius cephalus (Linnaeus, 1758); and bitterling, Rhodeus amarus (Bloch, 1782) (see Fedorčák et al. 2015). Loaches of the $C$. elongatoides $\times C$. tanaitica hybrid complex (Lusk et al. 2003, Lusková et al. 2004, Papoušek et al. 2008) were eudominant in the river (Tischler 1955). Fish catching was legally arranged based on a permit of the Ministry of Environment 759/2010-2.1 (4120/2014$2.3)$ and by special electrofishing permit (31/2015).

In total, 158 loaches were sampled ( 88 on 18-19 August 2014, and 70 on 29-30 September 2014) by electrofishing (200-300 V, 0.2-0.5 A; Table 1). Immediately after capture all fish were anaesthetised, then a fin clip was taken and fixed in $70 \%$ ethanol. Selected individuals were labelled, packaged separately, and frozen at $-10^{\circ} \mathrm{C}$. The remaining specimens were released back into the stream after measuring body length (standard length [SL] to the nearest $0.1 \mathrm{~mm}$ ) and body weight ( $W$; with $0.01 \mathrm{~g}$ accuracy). In total, 132 fish were used for age and growth analyses. Of the 158 fish sampled, 20 were excluded from the further analysis, as they were triploid males, tetraploids, or juveniles. Additional 6 fish were classified as outliers or were rejected due to damage caused during evaluation.

Ploidy status was determined from each fin clip as erythrocyte DNA content using a Partec CCA flow cytometer (Partec GmbH, Munster, Germany), using 49.6-diamidino-2-phenylindol.

Sex was determined morphologically in the field and via visual or microscopic observation of the gonads in the laboratory after dissection. The presence of Canestrini's scales on the pectoral fin, as well as the pectoral fins more pointed shapes, easily differentiated males from females. Age determination. Although scales are commonly used for age determination in the Cobitis genus, the lack of a calcified centre (Fig. 1) makes such estimations ambiguous. Therefore, in our study, age was estimated on the basis of the total number of annuli visible on the interior of the vertebral body (Fig. 2). That part of the spine between the beginning and end of the dorsal fin was dissected from each specimen. The spines were boiled for $10 \mathrm{~min}$ in water, mechanically cleaned, and fixed in $70 \%$ ethanol. For individual age estimation, at least three vertebrae were observed microscopically (Leica DM 2000, PLANOPO 1.0×). Radii and annual increments were measured using Leica Software. The distances from the vertebra's centre to each annual ring (rn) and to the vertebra edge ( $R=$ total radius) were measured to the nearest 0.005 $\mathrm{mm}$. The evaluated samples were classified by age.

Data analysis. Fish were evaluated for ploidy and sex status and labelled as follows: $2 \mathrm{nM}=$ diploid male, $2 \mathrm{nF}$ $=$ diploid female, $3 \mathrm{nF}=$ triploid female. The $L-W$ relation was determined using the equation (Le Cren 1951)

$$
W=a \mathrm{SL}^{b}
$$

transformed by taking the natural logarithm into

$$
\ln (W)=\ln (a)+b \ln (L) ;
$$

Table 1

Ploidal identity and the frequency of the Cobitis specimens sampled from the Okna River between August and

\begin{tabular}{|c|c|c|c|c|c|c|c|c|c|c|c|c|c|c|c|c|c|c|c|c|}
\hline \multirow{3}{*}{ Month } & \multicolumn{3}{|c|}{ Male } & \multirow{3}{*}{$\frac{\text { Female }}{2 n 3 n 4 n}$} & \multicolumn{3}{|c|}{ Juvenile } & \multicolumn{5}{|c|}{ Frequency by sex } & \multicolumn{6}{|c|}{ Frequency by ploidy } & \multirow{2}{*}{\multicolumn{2}{|c|}{ Total }} \\
\hline & \multirow{2}{*}{$2 n$} & \multirow{2}{*}{$3 n$} & \multirow{2}{*}{$4 n$} & & \multirow{2}{*}{\multicolumn{3}{|c|}{$2 n 3 n 4$}} & $\mathrm{M}$ & \multicolumn{2}{|c|}{$\mathrm{F}$} & \multicolumn{2}{|c|}{$\mathrm{J}$} & \multicolumn{2}{|c|}{$2 n$} & \multicolumn{2}{|c|}{$3 n$} & \multicolumn{2}{|c|}{$4 n$} & & \\
\hline & & & & & & & & $n \quad \%$ & $n$ & $\%$ & $n$ & $\%$ & $n$ & $\%$ & $n$ & $\%$ & $n$ & $\%$ & $n$ & $\%$ \\
\hline Aug & 22 & 3 & 2 & $\begin{array}{lll}33 & 17 & 1\end{array}$ & 2 & 7 & 1 & 2730.6 & 51 & 58.0 & 10 & 11.4 & 57 & 64.7 & 27 & 30.7 & 4 & 4.6 & 88 & 100 \\
\hline Sep & 34 & & & 1814 & 2 & 2 & & 3448.6 & 32 & 45.7 & 4 & 5.7 & 54 & 77.1 & 16 & 22.9 & & & 70 & 100 \\
\hline Total & 56 & 3 & 2 & $\begin{array}{lll}51 & 31 & 1\end{array}$ & 4 & 9 & 1 & 61 & 83 & & 14 & & 111 & & 43 & & 4 & & 158 & \\
\hline
\end{tabular}
September 2014

$\mathrm{M}=$ males, $\mathrm{F}=$ females, $\mathrm{J}=$ juveniles; $2 \mathrm{n}=$ diploids, $3 \mathrm{n}=$ triploids, $4 \mathrm{n}=$ tetraploids. 


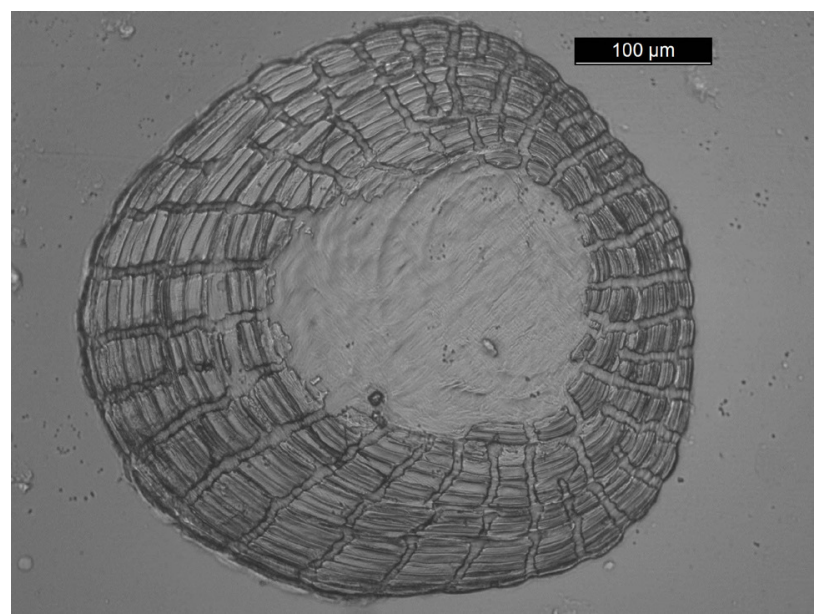

Fig. 1. A scale from $92 \mathrm{~mm}$ (SL) long diploid female (2nF) Cobitis collected from the Okna River, Slovakia; Note the blurred annual increments at the centre

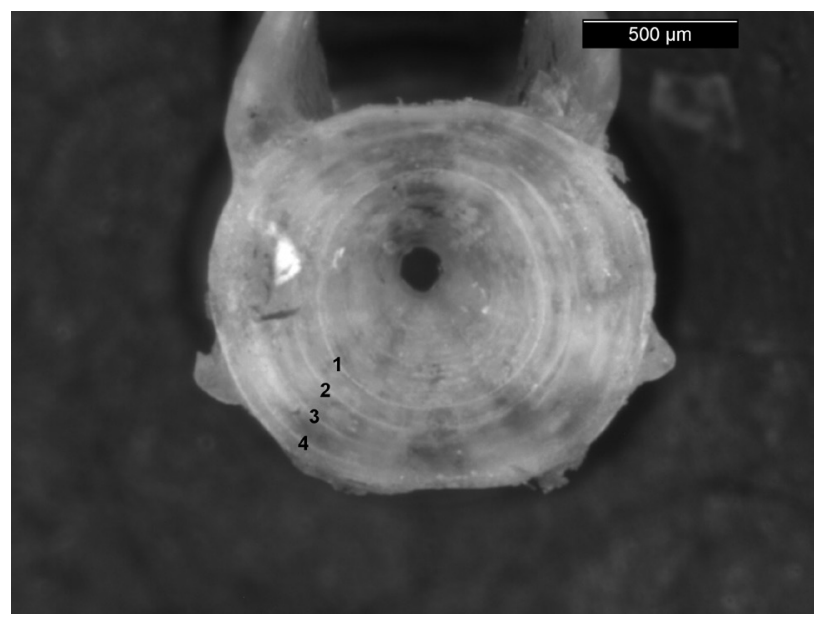

Fig. 2. Anterior view of the anterior part of a vertebra of a $96 \mathrm{~mm}$ (SL) long female Cobitis collected from the Okna River, Slovakia; Numbers indicate sequential annual increments

where $W$ is fish body weight [g], $L$ is fish body length [mm], $a$ is the regression intercept, and $b$ is the slope of the regression coefficient. For $L-W$ evaluation we fitted a linear model (LM) with (ln) weight as the response variable, and ( $(n)$ length, three ploidy-sex groups and their two-way interaction as explanatory variables. Significance of each regression we estimated by analysis of variance (ANOVA), comparison between regressions was carried out analysis of covariance (ANCOVA).

Back-calculated lengths (BCL) for each year of life of each individual were calculated using the direct proportion method (Dahl 1907, Lea 1910) as the regression relation between SL and R:

$$
\mathrm{BCL}=\mathrm{SL}\left(\mathrm{rn} \cdot R^{-1}\right)
$$

where BCL is back calculating length at the annulus, $\mathrm{SL}$ is length at capture, $\mathrm{rn}$ is age structure radius at the annulus, and $R$ is age structure radius at capture (Fig. $3)$. The BCL was evaluated using package Fisheries Stock Assessment package according to Ogle (2013). In order to determine whether back-calculated length-atage differed between the $2 \mathrm{nM}, 2 \mathrm{nF}$, and $3 \mathrm{nF}$ ploidy-sex group, we fitted a second-degree polynomial (quadratic) linear model. The model's right-side contained the group factor variable (ploidy-sex), with increments (inc) and the squared version of increments (incSqrd) as quantitative explanatory variables (quadratic regression); and the interaction between group factor (ploidy-sex) and both quantitative explanatory variables (increments). The model was submitted to analysis of covariance in the order to extract the Type I and type III sum of squares according to Fox and Weisberg (2011).

All statistical analyses were performed in the $\mathrm{R}$ statistical environment ( $\mathrm{R}$ Core Team 2014), with $\alpha=0.05$ set as the level of significance for all tests. The Akaike information criterion (AIC) was applied in the case of multiple $L-W$ model comparisons.

\section{RESULTS}

Ploidy status, size, and sex ratio. Loach from the Okna River were in $70.3 \%$ diploids and in $29.7 \%$ polyploids (Table 1). Of 132 Cobitis sp. identified, 40 were diploid males, whereas 54 of 92 females were diploid and 38 triploid. The overall sex ratio $(\mathrm{M}: \mathrm{F}=1: 2.3)$ was significantly biased toward females $\left(\chi^{2}=20.5, \mathrm{df}=1, P\right.$ $<0.01)$. The percentage of diploid males and females and triploid females varied within age classes (Table 2). Diploid males dominated the age classes at both $1+$ and $2+(1+$ : $50 \%, \chi^{2}=16.6, \mathrm{df}=2, P<0.01 ; 2+: 56.9 \%, \chi^{2}=37.9, \mathrm{df}=$ $2, P<0.01)$. At $3+$, however, diploid females dominated at $50 \%$ of the category $\left(\chi^{2}=32.6, \mathrm{df}=2, P<0.01\right)$; while at the $4+$, triploid females were highly dominant at $87.5 \%\left(\chi^{2}\right.$ $=134.4, \mathrm{df}=2, P<0.01)$. In general, females were longer than the males (ANCOVA, $F_{(1,130)}=102.1, P<0.01$ ), with ploidy having a significant effect also (ANCOVA, $F_{(2,129)}$ $=64, P<0.01)$. Tukey's test confirmed that each of the compared displayed significantly different lengths $(P<$ $0.05)$. The $95 \%$ confidence intervals produced by Tukey's test were -25 and $-16.3 \mathrm{~mm}$ between diploid males and females; -11.6 and $-2.8 \mathrm{~mm}$ between triploid and diploid females and 8.7 and $18.2 \mathrm{~mm}$ between triploid females and diploid males (Table 2).

Age and growth. Determination of age based on vertebrae indicated four age groups $(1+$ to $4+)$ for females, three $(1+$ to $3+$ ) for males (Table 2). Juveniles $(0+)$ based on the presence of any vertebrae annulus were not recorded in any of the groups examined $(2 \mathrm{nM}, 2 \mathrm{nF}, 3 \mathrm{nF})$. Males were most frequent at age classes $2+$, while diploid females were most frequent at $3+$ class and triploid females at $4+$. The oldest male specimens caught were aged $3+$. The largest number of females caught were in the third $(2+)$ or fourth $(3+)$ year of life, and the lowest number in their second $(1+)$ or fifth $(4+)$ years (Table 2). Females therefore, became more predominant in the population with each increasing age class. 
Table 2

Basic genetic, morphometric, and statistic, information on the Cobitis specimens collected from the Okna River, Slovakia

\begin{tabular}{|c|c|c|c|c|c|c|c|c|c|c|c|c|}
\hline \multirow{4}{*}{ Age } & \multicolumn{12}{|c|}{ Ploidy group } \\
\hline & \multicolumn{4}{|c|}{$2 \mathrm{nM}$} & \multicolumn{4}{|c|}{$2 \mathrm{nF}$} & \multicolumn{4}{|c|}{$3 \mathrm{nF}$} \\
\hline & \multicolumn{2}{|c|}{$\mathrm{SL}[\mathrm{mm}]$} & \multicolumn{2}{|c|}{ Frequency } & \multicolumn{2}{|c|}{$\mathrm{SL}[\mathrm{mm}]$} & \multicolumn{2}{|c|}{ Frequency } & \multicolumn{2}{|c|}{$\mathrm{SL}[\mathrm{mm}]$} & \multicolumn{2}{|c|}{ Frequency } \\
\hline & Mean & Range & $n$ & $\%$ & Mean & Range & $n$ & $\%$ & Mean & Range & $n$ & $\%$ \\
\hline $1+$ & 61.3 & $60-63$ & 3 & 50.0 & 53.0 & $52-54$ & 2 & 33.3 & 53.0 & & 1 & 16.7 \\
\hline $2+$ & 65.7 & $55-74$ & 33 & 56.9 & 81.7 & $71-89$ & 21 & 36.2 & 68.0 & $58-76$ & 4 & 6.9 \\
\hline $3+$ & 68.5 & $67-70$ & 4 & 6.7 & 91.7 & $75-104$ & 30 & 50.0 & 78.3 & $64-88$ & 26 & 43.3 \\
\hline $4+$ & - & - & - & - & 89.0 & - & 1 & 12.5 & 92.4 & $86-96$ & 7 & 87.5 \\
\hline All & 65.6 & $55-74$ & 40 & 30.3 & 86.3 & $52-104$ & 54 & 40.9 & 79.1 & $53-96$ & 38 & 28.8 \\
\hline
\end{tabular}

$2 \mathrm{nM}=$ diploid males, $2 \mathrm{nF}=$ diploid females, $3 \mathrm{nF}=$ triploid females; $\mathrm{SL}=$ standard length of fish.

The body length of 132 individuals increased proportionally with age. Length of vertebra radius showed a highly significant relations with standard length $\left(\mathrm{LR}, F_{(1,}\right.$ ${ }_{130)}=247.1, P<0.01$ ) (Fig. 3). Furthermore, differences BCL were significantly correlated with annual length increments (squared version) in interaction with ploidysex status (ANCOVA, $F_{(2,326)}=4.01, P<0.05$ ). Annual increments in diploid females $(2 \mathrm{nF})$ were significantly different from those of diploid males $(2 \mathrm{nM})$ and triploid females (3nF) (Fig. 4). During the first year of life, the annual length increment in diploid females $(2 \mathrm{nF})$ was the most robust (Fig. 4), with that of diploid males (2nM) lower and that of triploid females $(3 \mathrm{nF})$. In contrast to short-lived diploid males $(2 \mathrm{nM})$, triploid females $(3 \mathrm{nF})$ growth rate were higher in the older age groups. There was a tendency for the growth rate to decrease with age in all groups.

We were unable to confirm any significant differences in the slope of partial $L-W$ in sexual males $(2 \mathrm{nM})$, sexual females $(2 \mathrm{nF})$, and asexual females $(3 \mathrm{nF})$ (ANCOVA, $F_{(2}$, $\left.{ }_{123)}=2.56, P>0.08\right)$. On other hand, the differences in the $L-W$ relation between males and females were supported by the significant influence of sex on relative (ln) somatic weight (ANCOVA, $F_{(1,125)}=7.75, P<0.01$ ) (Table 3 ). Based on the Student's $t$ test diploid females $(b=2.55, \pm$ $\mathrm{SE}(b)=0.17, P<0.05)$, diploid males $(b=1.9, \pm \mathrm{SE}(b)$ $=0.27, P<0.01)$ and triploid females $(b=2.62, \pm \mathrm{SE}(b)$ $=0.18, P<0.05)$ all displayed negative allometric growth.

\section{DISCUSSION}

The sex ratio is slightly biased toward females in the majority of Cobitis species (Bohlen and Ritterbusch 2000), and more so in mixed diploid-polyploid populations (Erős 2000) due to the presence of triploid females. Hence, the diploid-polyploid ratio in mixed populations will affect the sex ratio. In our study, the diploid-polyploid ratio of $2.4: 1$ and sex ratio of males to females of $1: 1.4$ is considered. The diploid-polyploid ratio of Cobitis from Lake Müggelsee (Germany), however, at $1: 7.4$, is considered extreme, sex ratio 1 : 22 in favour of females (Bohlen and Ritterbusch 2000). According to Kotusz et al. (2014), the diploid-polyploid

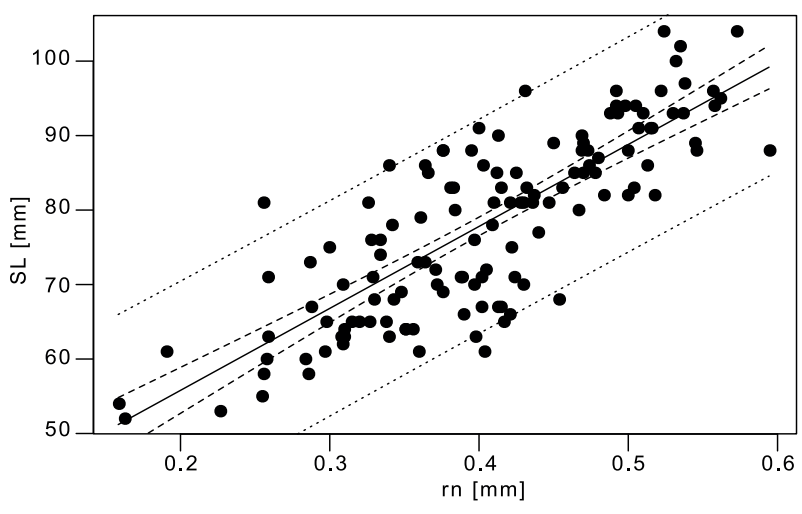

Fig. 3. Linear regression for the relation between standard length (SL) and vertebrae radius (rn) of the Cobitis specimens collected from the Okna River, Slovakia ( $n$ $=132 ; a=110.1, \pm \mathrm{SE}(a)=7, b=33.5, \pm \mathrm{SE}(b)=2.9$, $\left.r^{2}=0.66, P<0.01\right)$; The dashed lines represent the $95 \%$ confidence intervals, the dotted lines $95 \%$ prediction intervals and the full line the regression

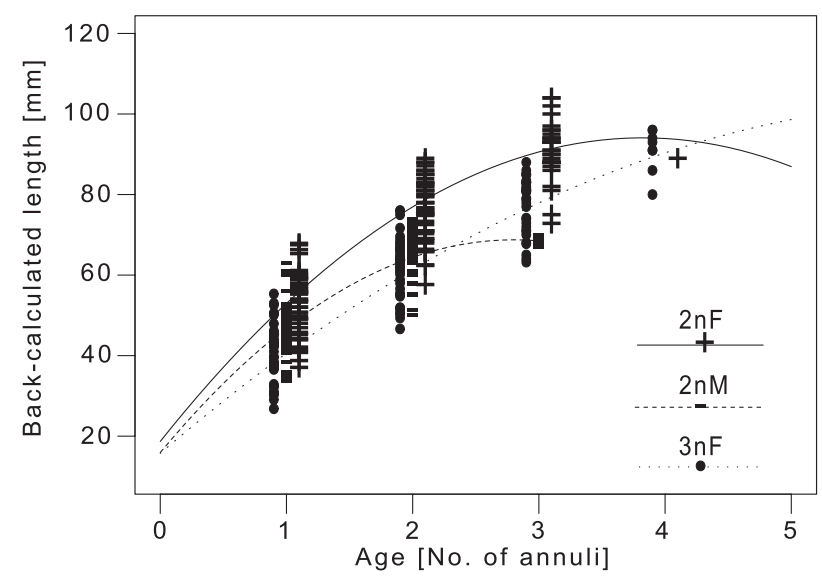

Fig. 4. Back-calculated lengths (BCL) of the Cobitis specimens (collected from the Okna River, Slovakia) at age, computed by the Dahl-Lee method; $2 \mathrm{nF}$ (diploid females): $y=-5.16 x^{2}+39.4 x+18.7\left(r^{2}=0.84\right) ; 2 \mathrm{nM}$ (diploid males): $y=-6.5 x^{2}+37.7 x+15.9\left(r^{2}=0.84\right) ; 3 \mathrm{nF}$ (triploid females): $y=-2.08 x^{2}+27 x+15.7\left(r^{2}=0.84\right)$ 
Table 3

Linear regression parameters for the relation between $(\ln )$ body weight and $(\ln )$ standard length of the Cobitis specimens collected from the Okna River, Slovakia

\begin{tabular}{cccccccccc}
\hline \multirow{2}{*}{ Model } & Level & \multicolumn{7}{c}{ Linear regression parameters } & \multirow{2}{*}{ ANCOVA } \\
\cline { 3 - 8 } & & $a$ & $\mathrm{SE}(a)$ & $b$ & $\mathrm{SE}(b)$ & $r^{2}$ & $n$ & $P$ & \\
\hline Model 1 & $2 \mathrm{nM}$ & 1.90 & 0.34 & -7.02 & 1.44 & 0.92 & 40 & $<0.06$ & $F_{(2,123)}=2.56 ; P=0.08$ \\
& $2 \mathrm{nF}$ & 2.55 & 0.19 & -9.86 & 0.83 & 0.92 & 52 & $<0.01$ & \\
& $3 \mathrm{nF}$ & 2.62 & 0.24 & -10.27 & 1.08 & 0.92 & 37 & $>0.78$ & \\
Model 2 & Males & 1.90 & 0.32 & -7.12 & 1.33 & 0.91 & 40 & $<0.01$ & $F_{(1,125)}=7.75 ; P<0.001$ \\
& Females & 2.77 & 0.12 & -10.92 & 0.51 & 0.91 & 89 & $<0.01$ & \\
\hline
\end{tabular}

$a=$ regression intercept, $b=$ slope of the regression coefficient, SE $(a)=$ standard error of the mean of $a$, SE $(b)=$ standard error of the mean of $b ; 2 \mathrm{nM}=$ diploid males, $2 \mathrm{nF}=$ diploid females, $3 \mathrm{nF}=$ triploid females; Model 1 includes interaction with ploidy-sex relation at three levels; Model 2 includes interaction with sex only, at two levels; Model accuracy: Model 1: AIC 179, df= 7; Model 2: AIC 169.2, df=5;

ratio in Cobitis population has remained relatively stable for around a decade, though the male-female ratio varies with age in the majority of populations (Soriguer et al. 2000, Patimar et al. 2011, Mousavi Sabet et al. 2011, 2012, Kırankaya and Ekmekçi 2014). As such, the survival rate differs between the sexes (Aoyama 2007, Juchno and Boron 2010) and between individuals of different ploidies (Bobyrev et al. 2003).

Cobitis males from the Okna River were smaller than the females, which is a fixed biological feature of all Cobitis species (Boroń et al. 2008). Moreover, males remain small throughout their life cycle in response to the specific requirements of the breeding rituals (Bohlen 2008). Overall, the age and length structures in European Cobitis populations show a general pattern of short lifespan (max. 6+ years) and body length (ca. $120 \mathrm{~mm}$ ) (Kırankaya and Ekmekçi 2014).

Organismal growth depends on an increase in the number of cells through replication of DNA content (Lee et al. 2009). Here, we show that growth in Cobitis sp. can be impacted by differing ploidy status. While very similar growth rates were observed for diploid males $(2 \mathrm{nM})$ and triploid females $(3 \mathrm{nF})$, especially until their second years of life, annual growth rate for diploid females $(2 \mathrm{nF})$ was significantly higher. According to life history theory, the cost of early maturity entails a reduction in lifespan, with more robust growth in the earlier life stages influencing subsequent longevity, an occurrence known as Rosa Lee's phenomenon (Ricker 1969). In our study diploid females $(2 \mathrm{nF})$ were most strongly represented at younger age classes and had a higher BCL compared to triploid females $(3 \mathrm{nF})$. While the body growth is known to be impacted by changes in energy balance during gonad growth any such increase in the energetic investment of triploid Cobitis remains questionable. Although triploid female of spined loach C. taenia from the Bug River have been shown to produce bigger oocytes (Juchno et al. 2007), the weight of ovaries remained the same for both diploid and triploid fish in the same population (Juchno and Boron 2010). As regards the survival rate, Cal et al. (2006) describe $91.9 \%$ of diploid and $100 \%$ of triploid turbots, Scophthalmus maximus (Linnaeus, 1758), as surviving, after reaching sexual maturity. Further, significantly better growth has been recorded in induce triploid tench, Tinca tinca (Linnaeus, 1758), and Atlantic salmon, Salmo salar Linnaeus, 1758, under aquacultural conditions. The artificial triploids are sterile and their enhanced growth is explained by constant growth, similar to most fish during the non-spawning season (Suzuki et al. 1985, Qin et al. 1998). In some cases, the length of natural diploids and triploids does not differ within each age class, suggesting that triploid growth rates can be equal to those of diploids (Takada and Tachihara 2009).

Within the genus Cobitis, strains with different ploidy display high morphological similarity (Kotusz 2008), though they clearly differ in physiological and ecological performance, including metabolic rate (Maciak et al. 2011), body condition, and habitat preference (Kotusz et al. 2014), and length of spawning period and oocyte size (Juchno et al. 2007). All these findings support the opinion that the two different forms (diploid and polyploid) representing different reproductive strategies and may differ in ecological niche utilisation (Kotusz et al. 2014).

The $L-W$ regression slopes in this study were estimated at 1.9 for adult males, 2.55 for diploid females, and 2.62 for triploid females (Table 3 ). These values are somewhat lower than those from previous studies, with Erös (2000) obtaining the value of 3.15 (SL 21-98 mm) for both sexes, Treer et al. (2008) recording 3.04 (SL 52-146 mm) for Croatian populations; Halačka and Pekárik (2015) 3.17 (SL 55-85 mm) for diploid males, 3.3 (SL 55-85 mm) for small diploid females and $2.92(\mathrm{SL}>85 \mathrm{~mm})$ for large diploid females. In our case, we are convinced that the lower slope values recorded were due to the absence of juvenile fish in this study. The mean coefficients obtained from the differing populations are consistent, the slight differences resulting from differing environmental conditions, season and/or day-night sampling. Our results also provide two further possible reasons for such differences, i.e., differences in the proportion of sexes and the absence of juvenile individuals.

In conclusion, while there were clear differences in condition between the sexes, there was no difference between strains of different ploidy. Additionally, habitat and season both had a significant effect on the $L-W$ relations. Crucially, both sexual and asexual 
females (natural polyploid hybrids), differed in growth performance, as shown by differing annual increase in body size.

\section{ACKNOWLEDGEMENTS}

These study was financed through research projects VEGA 1/0916/14, VEGA 1/0918/17, and GAČR P506/13$12580 \mathrm{~S}$ and through Grants No. GaPU 7/2016 and No. 003PU-2-3/2016 of the University of Prešov. We also gratefully acknowledge help from an Erasmus Student Mobility Grant. The authors would like to thank L. Pekárik and J. Ševc for consultation on our statistical procedures and K. Roche for help with language corrections.

\section{REFERENCES}

Anonymous 2003. Vyhláška č. 24/2003 Ministerstva životného prostredia Slovenskej republiky, ktorou sa vykonáva zákon č. 543/2002 Z. z. o ochrane prírody a krajiny. [Decree No. 24/2003 Coll. implementing some provisions of the act Low No. 543/2002 on protection of nature and landscape of 9 January 2003.] Slov-Lex 24/2003 Z.z. z 9-1-2003. [In Slovak.]

Anonymous 2015. The IUCN red list of threatened species. Version 2015-4. Available at http://www. iucnredlist.org.

Aoyama S. 2007. Sexual size dimorphism, growth, and maturity of the fluvial eight-barbell loach in the Kako River, Japan. Ichthyological Research 54 (3): 268-276. DOI: $10.1007 / \mathrm{s} 10228-007-0406-2$

Bobyrev A., Burmensky V., Vasil'ev V.P., Kriksunov E., Lebedeva E. 2003. Coexistence of triploid and diploid forms of spined loach, Cobitis taenia: a model-based approach. Folia Biologica 51 (Suppl.): 55-60.

Bohlen J. 2008. Spawning marks in spined loaches (Cobitis taenia, Cobitidae, Teleostei). Folia Zoologica 57 (1-2): 168-171.

Bohlen J., Ritterbusch D. 2000. Which factors affect sex ratio of spined loach (genus Cobitis) in Lake Müggelsee? Environmental Biology of Fishes 59 (3): 347-352.

DOI: $10.1023 / \mathrm{A}: 1007695703991$

Boroń A. 1999. Banded karyotype of spined loach Cobitis taenia and triploid Cobitis from Poland. Genetica 105 (3): 293-300.

DOI: $10.1023 / \mathrm{A}: 1003939813878$

Boroń A. 2003. Karyotypes and cytogenetic diversity of the genus Cobitis (Pisces, Cobitidae) in Poland: A review. Cytogenetic evidence for a hybrid origin of some Cobitis triploids. Folia Biologica 51 (Suppl.): 49-54.

Boroń A., Jeleń I., Juchno D., Przybylski M., Borzuchowska E. 2008. Age and growth of the karyologically identified spined loach Cobitis taenia (Teleostei, Cobitidae) from a diploid population. Folia Zoologica 57 (1-2): 155-161.

Cal R.M., Vidal S., Gómez C., Álvarez-Blázquez B., Martínez P., Piferrer F. 2006. Growth and gonadal development in diploid and triploid turbot (Scophthalmus maximus). Aquaculture 251 (1): 99-108.

DOI: $10.1016 /$ j.aquaculture.2005.05.010
Dahl K. 1907. The scales of herring as a means of determining age, growth and migration. Report on Norwegian Fishery and Marine Investigations 2 (6): $1-36,3$ plates.

Erôs T. 2000. Population biology of Cobitis elongatoides in a lowland stream of the Middle Danube (Hungary). Folia Zoologica 49 (Suppl. 1): 151-157.

Fedorčák J., Koščo J., Halačka K., Falatová L., Šmiga L., Ševc J., Hajdú J. 2015. Ichtyocenózy rieky Okny. [Fish fauna of Okna River.] Naturae Tutela 19 (2): 163-166. [In Slovak.]

Fox J., Weisberg S. 2011. An R companion to applied regression. 2nd edn. Sage Publications, Los Angeles, London, New Dehli, Singapore, Washington DC.

Halačka K., Pekárik L. 2015. Length-weight relationship of Cobitis elongatoides Heckel \& Kner, 1858 from a pure diploid population in the Nová Ríše Reservoir, Czech Republic. Journal of Applied Ichthyology 31 (3): 562-564.

DOI: $10.1111 /$ jai. 12710

Janko K., Flajšhans M., Choleva L., Bohlen J., Šlechtová V., Rábová M., Lajbner Z., Šlechta V., Ivanova P., Dobrovolov I., Culling M., Persat H., Kotusz J., Ráb P. 2007. Diversity of European spined loaches (genus Cobitis L.): An update of the geographic distribution of the Cobitis taenia hybrid complex with a description of new molecular tools for species and hybrid determination. Journal of Fish Biology 71 (Suppl. sc): 387-408. DOI: $10.1111 / \mathrm{j} .1095-8649.2007 .01663 . \mathrm{x}$

Janko K., Kotusz J., De Gelas K., Šlechtová V., Opoldusová Z., Drozd P. Choleva L., Popiołek M., Baláž M. 2012. Dynamic formation of asexual diploid and polyploid lineages: Multilocus analysis of Cobitis reveals the mechanisms maintaining the diversity of clones. PloS one 7 (9): e45384.

DOI: 10.1371 /journal.pone.0045384

Juchno D., Boroń A. 2010. Fecundity of the spined loach, Cobitis taenia (Pisces, Cobitidae) and natural allopolyploids of Cobitis from a diploid-polyploid population. Folia Zoologica 59 (1): 35-45.

Juchno D., Boroń A., Golaszewski J. 2007. Comparative morphology and histology of the ovaries of the spined loach Cobitis taenia L. and natural allopolyploids of Cobitis (Cobitidae). Journal of Fish Biology 70 (5): 1392-1411.

DOI: $10.1111 / \mathrm{j} .1095-8649.2007 .01419 . \mathrm{x}$

Kırankaya Ş.G., Ekmekçi F.G. 2014. Growth and reproduction of a stream population of Cobitis turcica in central Anatolia (Turkey). Journal of Applied Ichthyology 30 (2): 322-328. DOI: $10.1111 /$ jai.12375

Koščo J., Lusk S., Pekárik L., Košuthová L., Lusková V., Košuth P. 2008. The occurrence and status of species of the genera Cobitis, Sabanejewia, and Misgurnus in Slovakia. Folia Zoologica 57 (1-2): 26-34.

Kottelat M. 2012. Conspectus cobitidum: An inventory of the loaches of the world (Teleostei: Cypriniformes: 
Cobitoidei). The Raffles Bulletin of Zoology 2012 (26): 1-199.

Kotusz J. 2000. Intra- and interpopulation morphological variability in diploid and varied-ploidy Cobitis from Poland. Folia Zoologica 49 (Suppl. 1): 219-226.

Kotusz J. 2008. Morphological relationships between polyploid hybrid spined loaches of the genus Cobitis (Teleostei: Cobitidae) and their parental species. Annales Zoologici 58 (4): 891-905.

DOI: $10.3161 / 000345408 \times 396800$

Kotusz J., Popiołek M., Drozd P., De Gelas K., Šlechtová V., Janko K. 2014. Role of parasite load and differential habitat preferences in maintaining the coexistence of sexual and asexual competitors in fish of the Cobitis taenia hybrid complex. Biological Journal of the Linnean Society 113 (1): 220-235. DOI: $\underline{10.1111 / \text { bij. } 12329}$

Krčál J. 1965. Poznatky o veku a raste pĺža obyčajného (Cobitis taenia Linnaeus, 1758) z povodia Oravského priehradného jazera. [Notes to the age and growth of loach (Cobitis taenia Linnaeus, 1758) from Orava water Reservoir basin.] Biológia (Bratislava) 20 (12): 911-915. [In Slovak.]

Le Cren E.D. 1951. The length-weight relationship and seasonal cycle in gonad weight and condition in the perch (Perca fluviatilis). Journal of Animal Ecology 20 (2): 201-219. DOI: $\underline{10.2307 / 1540}$

Lea E. 1910. Contributions to the methodics used in herring-investigations. Pp. 7-33.

DOI: 10.1093/icesjms/s1.53.7 In: Hjort J. (ed.) Report on herring-investigations until January 1910. Conseil Permanent International pour l'Exploration de la Mer, Publications the Circonstance No. 53.

DOI: $10.1093 /$ icesjms/s1.53.1

Lee H.O., Davidson J.M., Duronio R.J. 2009. Endoreplication: Polyploidy with purpose. Genes and Development 23 (21): 2461-2477.

DOI: $10.1101 / \mathrm{gad} .1829209$

Lusk S., Koščo J., Halačka K., Lusková V., Flajšhans M. 2003. Identification of Cobitis from the Slovakian part of the Tisza basin. Folia Biologica 51 (Suppl.): 61-65.

Lusková V., Koščo J., Halačka K., Straňai I., Lusk S., Flajšhans M. 2004. Status of populations of the genus Cobitis in Slovakia. Biologia (Bratislava) 59 (5): 621-626.

Maciak S., Janko K., Kotusz J., Choleva L., Boroń A., Juchno D., Kujawa R., Kozlowski J., Konarzewski M. 2011. Standard metabolic rate (SMR) is inversely related to erythrocyte and genome size in allopolyploid fish of Cobitis taenia hybrid complex. Functional Ecology 25 (5): 1072-1078.

DOI: $10.1111 / \mathrm{j} .1365-2435.2011 .01870 . \mathrm{x}$

Mousavi Sabet H., Kamali A., Soltani M., Bani A., Esmaeili H.R., Rostami H., Vatandoust S., Moradkhani Z.2011.Age, reproduction, and fecundity of a population of Cobitis sp. (Actinopterygii: Cypriniformes: Cobitidae) from the Babolrud River in Southern Caspian Sea basin. Acta Ichthyologica et Piscatoria 41 (2): 117-122.

DOI: $\underline{\text { 10.3750/aip2011.41.2.07 }}$

Mousavi-Sabet H., Kamali A., Soltani M., Bani A., Rostami H. 2012. Age, sex ratio, spawning season, gonadosomatic index, and fecundity of Cobitis faridpaki (Actinopterygii, Cobitidae) from the Siahrud River in the southeastern Caspian Sea basin. Caspian Journal of Environmental Sciences 10 (1): 15-23.

Ogle D.H. 2013. FSA: fisheries stock analysis. R package version 0.3.5. R Foundation for Statistical Computing, Vienna.

Papoušek I., Lusková V., Koščo J., Lusk S., Halačka K., Povž M., Šumer Z. 2008. Genetic diversity of Cobitis spp. (Cypriniformes: Cobitidae) from different drainage areas. Folia Zoologica 57 (1-2): 83-89.

Patimar R., Amouei M., Mir-Ashrafi Langroudi M. 2011. New data on the biology of Cobitis cf. satunini from the southern Caspian basin (northern Iran). Folia Zoologica 60 (4): 308-314.

Pekárik L., Koščo J., Košuthová L., Košuth $\mathbf{P}$. 2008. Coenological and habitat affinities of Cobitis elongatoides, Sabanejewia balcanica and Misgurnus fossilis in Slovakia. Folia Zoologica 57 (1-2): 172-180.

Qin J.G., Fast A.W., Ako H. 1998. Growout performance of diploid and triploid Chinese catfish Clarias fuscus. Aquaculture 166 (3): 247-258. DOI: $10.1016 / \mathrm{s} 0044-8486(98) 00287-7$

R Core Team 2014. R: A language and environment for statistical computing. R Foundation for Statistical Computing, Vienna, Austria.

Ricker W.E. 1969. Effects of size-selective mortality and sampling bias on estimates of growth, mortality, production, and yield. Journal of the Fisheries Research Board of Canada 26 (3): 479-541.

DOI: $\underline{10.1139 / \mathrm{f} 69-051}$

Soriguer M.C., Vallespín C., Gomez-Cama C., Hernando J.A. 2000. Age, diet, growth and reproduction of a population of Cobitis paludica (de Buen, 1930) in the Palancar Stream (southwest of Europe, Spain) (Pisces: Cobitidae). Hydrobiologia 436 (1-3): 51-58.

DOI: $10.1023 / \mathrm{A}: 1026529720060$

Suzuki R., Nakanishi T., Oshiro T. 1985. Survival, growth and sterility of induced triploids in the cyprinid loach Misgurnus anguillicaudatus. Bulletin of the Japanese Society of Scientific Fisheries 51 (6): 889-894.

DOI: $10.2331 /$ suisan.51.889

Takada M., Tachihara K. 2009. Comparisons of age, growth, and maturity between male and female, and diploid and triploid individuals in Carassius auratus from Okinawa-jima Island, Japan. Aquatic Conservation: Marine and Freshwater Ecosystems 19 (7): 806-814.

DOI: $10.1002 /$ aqc. 1032

Tischler W. 1955. Synökologie der Landtiere. G. Fischer Verlag, Stuttgart, Germany. 
Treer T., Šprem N., Torcu-Koc H., Sun Y., Piria Vasil'ev V.P., Vasil'eva K.D., Osinov A.G. 1989. Evolution M. 2008. Length-weight relationships of freshwater fishes of Croatia. Journal of Applied Ichthyology 24 (5): 626-628.

DOI: $10.1111 / \mathrm{j} .1439-0426.2008 .01084 . \mathrm{x}$ of a diploid-triploid-tetraploid complex in fishes of the genus Cobitis (Pisces, Cobitidae). Pp. 153-169. In: Dawley R.M., Bogart J.P. (eds.) Evolution and ecology of unisexual vertebrates. Museum Bulletin 466, New York State Museum Albany, NY, USA.

Received: 12 August 2016 Accepted: 24 February 2017 Published electronically: 30 June 2017 